\title{
Slang Words Used by the Characters in Neighbors 2: Sorority Rising
}

\author{
Ni Made Dessy Ariyanti ${ }^{*}$, I Wayan Suardhana ${ }^{2}$, I Wayan Mulyawan ${ }^{3}$ \\ ${ }^{[123]}$ English Department, Faculty of Arts, Udayana University \\ ${ }^{1}$ [dessyariyanti09@gmail.com], ${ }^{2}$ [wayan_suardhana@yahoo.com] \\ *Corresponding Author
}

\begin{abstract}
The title of this study is Slang Words Used by The Characters in Neighbors 2: Sorority Rising. This study was conducted to identify the type and to analyze the function of slang words and phrases used by the characters in the movie "Neighbors 2: Sorority Rising". The data of this study were collected from "Neighbors 2: Sorority Rising" movie script. There were sixty-seven slang words or phrases found in the "Neighbors 2: Sorority Rising" movie script. Documentation method was used to collect the data. This study used the descriptive-qualitative method to analyze the data. There were only eighteen slang words or phrases analyzed based on the theory proposed by Allan and Burridge (2006) about types and functions of slang words. There are five types of slang found in the data. They are fresh and creative which was the most type of slang, imitative, acronym, clipping, and flippant. So, all the types of slang based on the theory were found. For the functions, there were seven functions of slang word found in the data. They are the functions of showing intimacy, addressing, forming intimate atmosphere, expressing impression, revealing anger, humiliating and initiating relax conversation. The function of showing intimacy is the most function in using slang found in the data.
\end{abstract}

\section{Keywords: slang words, type of slang, function of slang, characters}

\begin{abstract}
Abstrak
Judul dari peneliatian ini adalah kata-kata slang yang digunakan oleh karakter didalam neighbors 2: Sorority rising. Penelitian ini dilakukan untuk mengidentifikasi jenis dan menganalisis fungsi kata-kata dan frasa slang yang digunakan oleh karakter dalam film Neighbors 2: Sorority Rising. Data penelitian ini dikumpulkan dari naskah film. Ada enam puluh tujuh kata atau frasa slang yang ditemukan di naskah film tersebut. Metode dokumentasi digunakan untuk mengumpulkan data. Penelitian ini menggunakan metode deskriptif kualitatif untuk menganalisis data. Hanya delapan belas kata atau ungkapan slang yang dianalisis berdasarkan teori Allan dan Burridge (2006) mengenai jenis dan fungsi kata-kata slang di penelitian ini. Ada lima jenis slang yang ditemukan di data, yaitu segar and kreatif; tipe slang yang paling banyak digunakan adalah tiruan, singkatan, potongan, dan sembrono. Jadi, semua tipe slang berdasarkan teori ditemukan di dalam penelitian ini. Untuk fungsinya, ada tujuh fungsi kata slang yang ditemukan di data. Fungsi tersebut ialah fungsi untuk menunjukkan keintiman, memanggil, membentuk suasana intim, mengekspresikan kesan, mengungkapkan kemarahan, menghina dan memulai percakapan santai. Fungsi untuk menunjukan keintiman adalah fungsi slang yang paling banyak di temukan di data.
\end{abstract}

Kata kunci: kata-kata slang, tipe slang, fungsi slang, karakter

\section{Background of the Study}

Sociolinguistics is a study about the relationship between language and society (Holmes, 1992). It is a branch of macro linguistics which has been defined as the study of language in social context. In the society, people will live in a certain group of similar social and economic factors. People will speak a different language and use different 
social dialect according to the social group of the speaker. A social group is commonly identified based on some features, such as education, occupation, residential area, and income level. Hence, people having different social group tend to speak different social dialects in terms of words, pronunciation, and grammatical features. They will also apply certain words in communication. Those certain words are understood only in their group. In some situations, people in a certain group will use certain technical terms to express themselves. These certain expressions are known as slang. According to Hartmann and Stork (1972), slang is a variety of speech characterized by newly coined and rapidly changing vocabulary, used by young or by social groups for 'in-group' communication and thus tending to prevent understanding by the rest of the speech community. Thus, it is created from habits or ideas of people in social group as the creation of new words or importation of words from another language. Slang is used by people in certain social group to simplify utterance that they want to emphasize. It is not acceptable in formal situation and usually used in the informal situation as the daily language. Slang is interesting to be discussed because it is not only used in daily conversation in the real life. The usage of slang can also be seen in a movie because movie reflects the usage of language and daily conversation in society. One of the movies which use many slangs is an American movie "Neighbors 2: Sorority Rising". The movie is a comedy movie. There are many slang words used in the conversation among the characters in the movie. The script of the movie is used as the data source in which the slang words were found and analyzed in this study.

\section{Problems of the Study}

a) What type of slang words are used by the characters in "Neighbors 2: Sorority Rising"?

b) What are the function of slang words used by the characters in "Neighbors 2: Sorority Rising"?

\section{Aims of the Study}

a) To identify the types of slang used by the characters in "Neighbors 2: Sorority Rising"

b) To analyze the functions of slang used by the characters in "Neighbors 2: Sorority Rising"

\section{Research Method}

Research method is a systematic plan for conducting the research. In addition, it is the ways or procedures of understanding the objects that become target of subject. There were four steps of research methods used in this study as follows; data source, method and technique of collecting data, method and technique of analyzing data, and method and technique of presenting data analysis.

\subsection{Data source}

The data source was in the form of movie script. The movie script was taken from

http://www.springfieldspringfield.co.uk/ and the title is Neighbors 2: Sorority Rising. It is written by Nicholas Stoller, Andrew J, Cohen, Brendan O'Brien, Seth Rogen and Evan Goldberg. Neighbors 2: Sorority Rising is an American comedy movie directed by Nicholas Stoller which is receiving mostly positive reviews and grossed \$108 million worldwide. It is a kind of comedy movie which uses informal language featuring tons of crass jokes. The main characters in the movie are Mac and Kelly. Slang words were chosen as the data used by the characters in the movie. The movie was chosen because it contains the reflection of 
human life, from the act until the usage of language in conversation to communicate with someone else and because the characters in the movie use many slang words in their conversations. In the movie, the usage of slang used as in real life can be seen.

\subsection{Method and technique of collecting data}

The method of collecting data was documentation method. Documentation is the way of collecting data which document refers to all kind of written record. The total of the collected data was sixty-seven. The process of collecting data was divided into several steps. First, reading the movie script carefully in order to find slang words. Second, selecting the slang word in the movie script and checking it on the Online Slang Dictionary in order to know if it is a slang word or not. Third, taking a note of the selected slang words found in the movie script.

\subsection{Method and Technique of Analyzing Data.}

The collected data were analyzed the using qualitative method. It was used to describe the type of slang and the function in using slang found in the movie script entitled "Neighbors 2: Sorority Rising". The categorization of slang words was based on the Online Slang Dictionary (OSD). There were sixty-seven collected data and only eighteen data were analyzed because those words represented the other words which have the same type and function. It took several steps to analyze the data. First, identifying the type of slang words or phrases and second, analyzing the function of slang words or phrases based on theory of type and function of slang by Allan and Burridge (2006).

\subsection{Method and Technique of Presenting Data}

Formal and informal method was used in presenting data analysis. Sudaryanto (1993) stated that formal method means that the data analysis is presented using symbol, tables, and diagrams while informal method means that the data analysis is presented by using words and sentences. Formal method was used in presenting the data of the study. Informal method was used in presenting the analysis discussion of the data. It means that the data analysis is presented descriptively. There were several steps in presenting data analysis. First, presenting the data in a table and it was preceded by the definition of the object of the study. Second, data were followed by the analysis discussion of the data which were presented based on the theory in words or sentences and in the form of paragraphs, first one for the type of slang and the second one for the function of slang.

\section{Result and discussion}

Here are the analyses of slang word found in movie script of Neighbors 2: Sorority Rising.

\subsection{Data 1}

\section{Type of Slang:}

Fresh and Creative

The slang word that is an up to date word and it has cleverness imagination.

\section{Function of Slang:}

\section{To Address}

The speaker use slang word to address another speaker in order to maintain their close relationship 
Table of Data:

\begin{tabular}{lll}
\hline \multicolumn{1}{c}{$\begin{array}{c}\text { Description of } \\
\text { Data }\end{array}$} & $\begin{array}{c}\text { Type } \\
\text { of } \\
\text { Slang }\end{array}$ & $\begin{array}{c}\text { Function of } \\
\text { Slang }\end{array}$ \\
\hline $\begin{array}{l}\text { Kelly: Honey, I'm } \\
\text { completely and }\end{array}$ & $\begin{array}{l}\text { Fresh } \\
\text { and }\end{array}$ & To Address \\
totally....Sorry. & Creativ & \\
$\begin{array}{l}\text { Baby, I think I } \\
\text { might be pregnant. }\end{array}$ & $\mathrm{e}$ & \\
$\begin{array}{l}\text { Mac: That's great! } \\
\text { Sweetie, that's } \\
\text { fantastic! }\end{array}$ & & \\
\hline
\end{tabular}

\section{Analysis: \\ From the conversation above, the} slang word which is analyzed is sweetie. The word sweetie is classified into fresh and creative type of slang. It is because the word sweetie describes something in informal situation and also it is an up to date word and it has cleverness imagination. According to OSD, the slang word sweetie means affectionate form of address or reference for one's significant other. This word is usually used to address someone. It can be seen from the data above, the speaker says "That's great! Sweetie, that's fantastic!". The word sweetie refers to his wife and it describes that he adores her by dressing her sweetie. The participants of the conversation in the data above are Mac and Kelly. Mac and Kelly are the main characters in the movie. Kelly tells Mac about her pregnancy. Mac replays it by saying "That's great! Sweetie, that's fantastic!". Here, the sentence "that's fantastic" means about the pregnancy and the word before that sentence "sweetie" means his wife. So, the word sweetie has a function to address. In the situation of the conversation above, the speaker uses slang word to address another speaker in order to maintain their close relationship.

\subsection{Data 2}

\section{Type of Slang:} Flippant

The slang word made by two or more in which the word composed not correlated with the denotative meaning.

\section{Function of Slang:}

\section{To Reveal Anger}

The speaker use slang word to express unpleasant or dislike felling of the speaker toward something.

Table of Data:

\begin{tabular}{|c|c|c|}
\hline $\begin{array}{l}\text { Description of } \\
\text { Data }\end{array}$ & $\begin{array}{l}\text { Type of } \\
\text { Slang }\end{array}$ & $\begin{array}{l}\text { Function of } \\
\text { Slang }\end{array}$ \\
\hline $\begin{array}{l}\text { Mac: Okay, look. } \\
\text { We've just gotta } \\
\text { convince them to } \\
\text { chill. }\end{array}$ & Flippant & $\begin{array}{l}\text { To reveal } \\
\text { anger }\end{array}$ \\
\hline $\begin{array}{l}\text { Kelly: We just } \\
\text { need them to } \\
\text { behave themselves. }\end{array}$ & & \\
\hline $\begin{array}{l}\text { Mac: We just ask } \\
\text { them not to party } \\
\text { while } \\
\text { escrow. }\end{array}$ & & \\
\hline $\begin{array}{l}\text { Kelly: We'll be } \\
\text { fine. }\end{array}$ & & \\
\hline $\begin{array}{l}\text { Mac: As soon as } \\
\text { we're not escrow, } \\
\text { go fucking ape } \\
\text { shit. }\end{array}$ & & \\
\hline
\end{tabular}

\section{Analysis :}

From the conversation above, the slang word which is analyzed is ape shit. The word ape shit is classified into flippant type of slang. It is classified into flippant type because the word ape shit is made up of two words in which the words composed not correlated with the denotative meaning. The slang word ape shit means crazy and it is a state of anger toward someone or something, it is based on OSD. Whereas, according to Oxford Dictionary, "ape" means a large animal like monkey and "shit", meaning solid 
waste matter passed from the bowels. It shows that the slang word ape shit is composed of words which are not correlated with its denotative meaning. The participants of the conversation above are Mac and Kelly. They are the main characters in the movie. The situation of the conversation above is when Mac and Kelly are in their neighbor's house where there is a party in it. The party is held by a group of young women which is also their new neighbor. They think that the party will bring bad effect in selling their house. It makes them angry. Then, the slang word ape shit is mentioned by Mac by saying "As soon as we're not escrow, go fucking ape shit" in high voice. The slang word ape shit has a function to reveal anger. There is the tendency to express unpleasant or dislike felling of the speaker toward something. The anger is major reason of using the kind of slang word. It can be seen from the meaning of ape shit and the context of the situation in the conversation when the slang word has been said. In addition, as the meaning of slang word ape, it can be concluded that that the slang word ape shit is used to reveal anger based on the data. It shows that Mac fells angry about their neighbor who held a party that is why he uses that slang word.

\subsection{Data 3}

\section{Type of slang:}

Imitative

The slang word is imitating the Standard English word.

\section{Function of Slang:}

\section{To Show Intimacy}

The speakers use slang word in purpose of showing their relationship.
Table of data:

\begin{tabular}{|c|c|c|}
\hline Description of Data & $\begin{array}{l}\text { Type of } \\
\text { slang }\end{array}$ & $\begin{array}{c}\text { Function } \\
\text { of slang }\end{array}$ \\
\hline $\begin{array}{l}\text { Mac: Are you okay, } \\
\text { man? }\end{array}$ & Imitative & $\begin{array}{l}\text { To show } \\
\text { intimacy }\end{array}$ \\
\hline $\begin{array}{l}\text { Jimmy: No, I'm not } \\
\text { okay, man. I'm } \\
\text { freaking out about } \\
\text { Paula having a baby. } \\
\text { I don't think I can do } \\
\text { it. }\end{array}$ & & \\
\hline $\begin{array}{l}\text { Mac: Dude, you're } \\
\text { gonna be a good } \\
\text { parent. Don't worry. }\end{array}$ & & \\
\hline $\begin{array}{l}\text { Jimmy: No, I'm not. } \\
\text { I don't know } \\
\text { anything. Do you } \\
\text { know you can't leave } \\
\text { a baby alone? If } \\
\text { you're at home and } \\
\text { you want the baby to } \\
\text { stay while you go see } \\
\text { a movie? } \\
\text { Unacceptable. }\end{array}$ & & \\
\hline
\end{tabular}

Analysis:

From the conversation above, the slang word analyzed is gonna. The word gonna is classified into imitative type of slang. It is classified into imitative type because the word gonna imitating the Standard English word: using Standard English word in different meaning or combining two different words. According to OSD, the slang word gonna is a contraction from phrase "going to". The participants of the conversation above are Mac and Jimmy. Mac and Jimmy are characters in the movie. Mac is the main character and Jimmy is the supporting character in the movie. The situation of the conversation above is when Mac and Jimmy are having lunch in their office. The conversation of the data above starts when Mac asks Jimmy if he is okay. Jimmy says he is not okay in high voice. The reason is that his wife is pregnant and he is not ready to be a father. Here, 
the slang word gonna is mentioned by Mac by saying "Dude, you're gonna be a good parent". Based on the context of the situation in the conversation above, the slang word gonna has a function to show intimacy. The theory says the speaker prefers to use slang variant rather than standard variant of vocabulary. They have tendency to use slang word in purpose of showing intimacy since slang can be an effective way of showing intimacy among participants. It is usually used for people who have close relationship with others, they will use certain choice of word when they speak or communicate to the others compared with people who have distant relationship. It can be seen from the context of the situation in the data, Mac uses slang word to show intimacy which means informal situation. It can be seen in the data that Mac uses the word "dude" to address Jimmy which indicates the conversation is between close friends. In contrast, if Mac addresses Jimmy with "sir", it indicates that the conversation is in formal situation.

\subsection{Data 4}

\section{Type of Slang:}

Acronym

The slang word is contracted by the result of word from the first letter of each word in a phrase.

\section{Function of Slang:}

\section{To Form Intimate Atmosphere}

The speakers use slang word in purpose of reducing social distant and more comfortable when having a conversation with a stranger.
Table of Data:

\begin{tabular}{|c|c|c|}
\hline $\begin{array}{l}\text { Description of } \\
\text { Data }\end{array}$ & $\begin{array}{l}\text { Type of } \\
\text { Slang }\end{array}$ & $\begin{array}{l}\text { Function } \\
\text { of Slang }\end{array}$ \\
\hline $\begin{array}{l}\text { Shelby: And like, } \\
\text { most importantly, } \\
\text { we can make sisters } \\
\text { for life. }\end{array}$ & Acronym & $\begin{array}{l}\text { To form } \\
\text { intimate } \\
\text { atmosphere }\end{array}$ \\
\hline
\end{tabular}

Nora: Yeah!

Beth: I wanna be your sister.

Nora: I wanna be your sister.

Shelby: Okay-Oh, my God! BFF!

\section{Analysis:}

From the conversation above, the slang word analyzed is BFF. The word BFF is classified into acronym type of slang. It is classified into acronym type of slang because the slang word BFF is the type of slang word constructed by the result of word from the first letter of each word in a phrase or this type is made by initials from a group of words or syllables. According to OSD, the slang word BFF is the acronym for Best Friend Forever which means as being best friend forever. From the data, the speaker mentions the slang word by saying "Okay-Oh, my God! BFF!" It is related to the previous sentence, "we can make sisters for life" which means making for really close relationship which is being best friend. The participants of the conversation above are Shelby, Nora, and Beth. They are the supporting characters in the movie. The slang word BFF is mentioned by Shelby when she is talking to Nora and Beth in the college dorm. They meet in the fraternity party and they don't really like the party. They have the same idea to get out from the party and come together in a room inside the college dorm. There, they agree to make their own woman group or sorority called Kappa Nu. Here, the slang word BFF has 
a function to form intimate atmosphere. This one of slang function which can be one alternative way to alleviate the relationship between the strangers will flow smoothly so that they can reduce social distance and more comfortable. Shelby uses the slang word BFF in order to make the atmosphere of the conversation more intimate and reduce social distance because they have just met then decided to be friends.

\subsection{Data 5 \\ Type of Slang: \\ Clipping}

The slang word is made by deleting some part of longer word become shorter form in the same meaning.

\section{Function of Slang:}

\section{To Show Intimacy}

The speakers use slang word in purpose of showing their relationship.

Table of Data:

\begin{tabular}{|c|c|c|}
\hline $\begin{array}{l}\text { Description of } \\
\text { Data }\end{array}$ & $\begin{array}{l}\text { Type of } \\
\text { Slang }\end{array}$ & $\begin{array}{c}\text { Function } \\
\text { of Slang }\end{array}$ \\
\hline \multicolumn{3}{|l|}{ Kelly: What? } \\
\hline Mac: Take it. & Clipping & To show \\
\hline $\begin{array}{l}\text { Kelly: Ladies, we } \\
\text { can come to some }\end{array}$ & & intimacy \\
\hline sort of & & \\
\hline $\begin{array}{l}\text { compromise here, } \\
\text { can't we? }\end{array}$ & & \\
\hline \multicolumn{3}{|l|}{$\begin{array}{l}\text { Shelby: I'm sure } \\
\text { maybe... }\end{array}$} \\
\hline \multicolumn{3}{|l|}{$\begin{array}{l}\text { Teddy: No means } \\
\text { no! } \\
\text { neighbors? }\end{array}$} \\
\hline Mac: Teddy? & & \\
\hline $\begin{array}{l}\text { Teddy: Welcome } \\
\text { to soon enough. }\end{array}$ & & \\
\hline
\end{tabular}

Analysis :

From the conversation above, the slang word analyzed is the word sup. It is classified into clipping type of slang. The slang word sup is classified into clipping is because the slang word sup is a type of slang word made by deleting some parts of longer word to become shorter form with the same meaning. According to OSD, the slang word sup is the short term for a word "what is up?". It is a term that cool people use because they are too lazy to say What is up? The word which is commonly used can be clipped into shorter form. In addition, clipping form is not appropriate to be used in formal conversation. From the data, the speaker says "'Sup, neighbors?" which means "what is up, neighbors?" The participants in the conversation above are Mac, Kelly, Shelby and Teddy. The situation of the conversation above is when Mac and Kelly come to the party at their neighbor's house. Mac and Kelly want to check if there is parent in it. Then, they beg them to stop the party because it is disturbing them. When they try to ask Shelby, Teddy comes and greets Mac and Kelly by saying "'Sup, neighbors?". The function of slang word sup is to show intimacy, the speaker prefers something to use slang variant than standard variant of vocabulary. They have tendency to use slang word in purpose of showing their relationship. It is usually used for people who have close relationship with others that they will use certain choice of words when they speak or communicate to others, compare with people who have distant relationship may use formal word. It can be seen from the context of the situation in the conversation when the slang word has been said. Teddy uses the slang word sup to show intimacy because they already knew each other. It can be seen when Teddy says "'Sup, neighbors?" to Mac and Kelly, Mac replays it surprisingly by saying "Teddy?" which means they already knew each other. 


\section{Conclusion}

Based on the analysis of chapter 3, it can be concluded that there were sixtyseven slang words and phrases found in the movie script. However, only eighteen slang words or phrases that have been analyzed because those words already represent the other word which has the same type and function of slang. The data have been analyzed based on the type and function of slang used by the characters in Neighbors 2: Sorority Rising.

The types of slang were divided into five types of slang based on the theory. Fresh and creative type of slang was the most type of slang used by the main characters. There were seven Fresh and creative types, four imitative types, three acronym types, and two clipping and flippant types. So, all the types of slang were found in the data.

For the functions, there are seven functions in using slang. From the data analyzed, the function to show intimacy is the most function in using slang found. There were five to show intimacy, three to address, to form intimate atmosphere and to express impression, two to reveal anger, one to humiliate and initiate relax conversation. The function of slang word was not analyzed based on the theory only but also based on the meaning and the context of situation when the slang word was used by the characters in the movie.

\section{References}

Allan, Keith and Burridge, Kate. 2006. Forbidden words: taboo and the censoring of language. Cambridge University Press.

Dewanti. 2015. Neighbors 2: Sorority Rising [Internet]. Available from: https://filmbor.com/neighbors2sorority-rising/.html [Accessed 14 June 2017]
Holmes, Janet. 1992. An Introduction to Sociolinguistics. London and Newyork: Longman

Oxford Dictionary. 2008. Oxford University Press

Rama, Andika. 2017. Slang in Miller's Deadpool Movie. (thesis). Udayana University, Denpasar.

Sudaryanto. 1993. Metode dan Aneka Teknik Analisa Bahasa. Yogyakarta : Duta Wacana University Press.

The Online Slang Dictionary [internet]. Available from: https://www.onlineslangdictionary. com

Wardaugh, R. 1986. An Introduction to Sociolinguistic. Oxford:Basil Blackwell 